\title{
Decision support framework to identify lakes that are likely to meet water quality targets if external inputs of phosphorus from agriculture are reduced
}

\author{
Linda May ${ }^{1},{ }^{*}$, Philip Taylor ${ }^{1}$, Bryan Spears ${ }^{1}$, Jo-Anne Pitt ${ }^{2}$, Adrian L. Collins ${ }^{3}$, Isabel Cork- \\ ley ${ }^{4}$, Steven Anthony ${ }^{4}$, David Skirvin ${ }^{4}$, David Lee ${ }^{4,5}$ and Pamela Naden ${ }^{6}$ \\ ${ }^{1}$ Centre for Ecology \& Hydrology, Bush Estate, Penicuik, Midlothian EH26 0QB, UK. \\ 2 Environment Agency, Station Road, Haddiscoe, Great Yarmouth NR31 9JA, UK. \\ ${ }^{3}$ Sustainable Agriculture Sciences Department, Rothamsted Research, North Wyke, Okehampton, Devon EX20 \\ 2SB, UK. \\ ${ }^{4}$ RSK ADAS, Titan 1 Offices, Coxwell Avenue, Wolverhampton Science Park, Stafford Road, Wolverhampton \\ WV10 9RT, UK. \\ ${ }^{5}$ Catapult Energy Systems, 7th Floor Canon House, The Priory Queensway, Birmingham B4 6BS, UK. \\ ${ }^{6}$ Centre for Ecology \& Hydrology, Maclean Building, Crowmarsh Gifford, Wallingford OX10 8BB, UK. \\ * Corresponding author: 1may@ceh.ac.uk
}

Received: 13/04/18

Accepted: 19/10/18

\begin{abstract}
Decision support framework to identify lakes that are likely to meet water quality targets if external inputs of phosphorus from agriculture are reduced

About $40 \%$ of European lakes are failing water quality targets for chemistry that have been set under the EU Water Framework Directive (WFD). One of the main causes of this problem is excessive inputs of phosphorus (P) to lakes from their catchments, including those from agricultural sources and wastewater treatment works. This study used WFD monitoring data from England and Wales to develop a method of identifying lakes that are failing WFD water quality targets for good status in terms of total phosphorus (TP) concentrations and whose problems could be solved by reducing P inputs from agricultural sources. A decision support framework is presented that (1) identifies lakes that are failing to achieve good status due to high TP inputs from agriculture; (2) predicts how in-lake TP concentrations are likely to respond to reduced inputs from agricultural sources, and (3) identifies sites where recovery is likely to be delayed by factors that induce resistance to TP mitigation measures. Through a worked example, we demonstrate how a decision support framework can be used to screen lake WFD monitoring data to identify where expensive restoration measures are likely to be more cost effective. We demonstrate that, in general, reducing the external TP load from agricultural sources would be effective only if introduced as part of a more comprehensive programme of restoration measures targeting other sources of TP, such as waste water treatment works, and taking into account lake-specific factors that affect lake response. The outputs from this decision support framework are designed to enable water managers to identify sites where recovery may be delayed by lake specific biological, chemical or physical characteristics, allowing them to manage expectations of the recovery process better by providing realistic timescales.
\end{abstract}

Key words: Eutrophication, restoration, catchment, runoff, nutrients

\section{RESUMEN}

Marco de referencia para identificar lagos que puedan cumplir los objetivos de calidad del agua si se reducen los aportes externos de fósforo de origen agrícola

Alrededor del $40 \%$ de los lagos europeos no cumplen con los objetivos de calidad química del agua que se han establecido en la Directiva Marco del Agua de la UE (DMA). Una de las principales causas es la entrada excesiva de fósforo (P) a los lagos 
proveniente de sus cuencas, ya sea por fuentes agrícolas o efluentes de plantas de tratamiento de aguas residuales. Este estudio utilizó datos de monitoreo de la DMA de Inglaterra y Gales para desarrollar un método para identificar lagos que no están cumpliendo con los objetivos de calidad del agua de la DMA en términos de concentraciones de fósforo total (TP) y cuyos problemas podrían resolverse reduciendo las entradas de P de fuentes agrícolas. Se presenta un marco de referencia para la toma de decisiones que (1) identifica los lagos que no logran alcanzar un buen estado debido a los altos aportes de TP de la agricultura; (2) predice cómo las concentraciones de TP en el lago parecen responder a aportes reducidos de fuentes agrícolas, y (3) identifica los sitios donde es probable que la recuperación se retrase debido a factores que inducen resistencia a las medidas de mitigación de TP. A través del ejemplo estudiado, demostramos cómo puede ser usado un marco de referencia para la toma de decisiones, que nos ayude a filtrar los datos de monitoreo de lagos de la DMA y poder identificar dónde son más efectivas las costosas medidas de restauración. También demostramos que en general, reducir la carga externa de TP de origen agrícola solo es efectivo si se introduce como parte de un programa de restauración más completo el cual tenga como objetivo identificar otras fuentes de TP, como por ejemplo las estaciones depuradoras, y teniendo en cuenta factores especificos de los lagos que afectan su respuesta. Los resultados también permiten a las personas encargadas de la gestión del agua identificar sitios donde la recuperación puede retrasarse por las características biológicas, químicas o físicas especificas del lago, lo que permite gestionar mejor las expectativas del proceso de recuperación al proporcionar escalas de tiempo realistas.

Palabras clave: Eutrofización, restauración, cuenca, escorrentía, nutrientes

\section{INTRODUCTION}

Many lakes across Europe have water quality targets that have been set under the EU Water Framework Directive (WFD) (European Parliament, 2000). In practice, these are mainly lakes with a surface area of more than $0.5 \mathrm{~km}^{2}$. Of these, about $40 \%$ (by surface area) are currently failing to achieve good status in relation to WFD water quality targets for chemistry (https://www. eea.europa.eu/data-and-maps/figures/percentageof-rivers-lakes-groundwater).

Although it is unlikely to be the only pressure that is degrading lake water quality, phosphorus (P) is often the main cause of the cyanobacterial blooms that restrict water use leading to economic impacts. For example, Wolf and Klaiber (2017) estimated that the value of properties in the USA situated within $600 \mathrm{~m}$ of waterbodies infested with algal blooms will be reduced by about $22 \%$. The main sources of $\mathrm{P}$ within a lake catchment vary from site to site, with some being dominated by agricultural sources and others by sewage related sources (Comber et al., 2018). To implement the cost effective improvement of water quality in lakes that have been adversely affected by excessive inputs of $\mathrm{P}$, it is important to explore the relative importance of different sources of $\mathrm{P}$ and the likely benefits of controlling them. In addition, consideration of factors that may potentially confound ecological recovery following catch- ment $\mathrm{P}$ reduction should be assessed, for example, internal loading (Serano et al., 2017. A growing body of literature is available in which the effects of catchment $P$ reduction and confounding factors are quantified, generally, providing scope to construct a decision support framework to accomplish this.

In England and Wales, about 763 waterbodies have been classified as 'lakes' under the WFD, i.e. lakes with a surface area greater than $0.5 \mathrm{~km}^{2}$. At the time of this study, many of these were being monitored by the Environment Agency for regulatory and reporting purposes. Although some lakes fail to achieve good status for other reasons, most failures to achieve good chemical status are caused by nutrient enrichment (eutrophication), with agricultural runoff and effluent from wastewater treatment works being the main external sources of these nutrients (e.g. Scottish Government, 2015).

The main aim of this study was to develop a method of identifying lakes that were failing WFD water quality targets for good status in terms of total phosphorus (TP) concentrations and whose problems could, potentially, be solved by reducing TP inputs from agricultural sources. A decision support framework has been developed that (1) identifies lakes that are failing to achieve good status due to high TP concentrations; (2) predicts how in-lake TP concentrations are likely to respond to reductions in TP inputs from agricul- 
tural sources, and (3) provides information on where lake recovery could be delayed, or even prevented, by factors that induce resistance to mitigation. These include internal recycling of $P$ within the lake, lake depth, fetch, hydraulic loading, the presence of benthivorous fish and the extent of the littoral zone (Janse et al., 2008).

\section{DATA AND METHODS}

\section{Lake and catchment specific values of key parameters}

\section{Lake and catchment characteristics}

Digital outlines of the WFD lakes and their catchments across England and Wales, and summary information on their size and shape, were obtained from the UK Lakes database (https://eip.ceh.ac.uk/ apps/lakes/detail.html). These data included a unique identifier (WBID) for each lake and physical characteristics such as mean depth, surface area, volume and catchment area.

\section{Lakes monitoring data and WFD water quality targets for TP concentrations}

The Environment Agency provided water quality monitoring data for 437 WFD lakes from across England and Wales. These data comprised in-lake TP concentrations that had been collected between 2008 and 2014. The methodology for collecting samples and analysing them for TP content was consistent across all lakes. Type or site specific TP boundary values for good/moderate status were also supplied.

\section{Hydraulic loads to lakes}

Water flow into each lake was estimated from Standard-period Average Annual Rainfall (SAAR) data at $1 \mathrm{~km}$ resolution and actual evaporation data from the Meteorological Office Rainfall and Evaporation Calculation System (MORECS; Hough \& Jones, 1997) at $40 \mathrm{~km}$ resolution. Mean values for each lake catchment were used to estimate hydrologically effective rainfall (HER). It was assumed that the land type coefficient of 0.7 (i.e. grassy surface) used to calculate MORECS evaporation data was representative of the whole catchment. The calculated value for HER (m) was combined with the catchment area $\left(\mathrm{m}^{2}\right)$ to give mean annual runoff into the lake from its catchment. HER falling directly onto the lake surface was calculated using the same data and a similar process, but the land type coefficient was increased to 1 to reflect the higher evaporation levels that would be likely to occur across the lake surface.

\section{Total phosphorus inputs to lakes}

Total phosphorus inputs to each lake were estimated using outputs from the SEPARATE (SEctor Pollutant AppoRtionment for the AquaTic Environment; version 2.0) cross sector screening tool (Zhang et al., 2014). SEPARATE integrates information on TP emissions from multiple sources to provide pollutant apportionment information and summarises these estimates for WFD inland water bodies (rivers) across England and Wales. The following sources are included: agriculture, wastewater treatment works, urban diffuse sources, storm tank overflows, septic tanks, combined storm overflows, river bank erosion and direct atmospheric deposition to water.

To estimate TP delivery to lakes from the WFD river catchment data provided by SEPARATE, total catchment TP loads were converted to specific TP loads (i.e. values per unit area of catchment) and then overlain onto the relevant lake catchments. Where the lake catchment polygons and the SEPARATE data intersected, new polygons were created with a unique identifier for each lake (WBID) and the corresponding TP specific load. For each lake catchment, these new polygons and TP loads were aggregated to provide whole-catchment loads. Lake catchments were excluded from the analysis if less than half of the catchment had data coverage or if the total area of the lake catchment was less than $25 \mathrm{~km}^{2}$, which is the limit of resolution of the agricultural source data currently included in SEPARATE.

\section{Average annual and maximum summer/autumn TP concentrations}

The WFD monitoring data were used to calculate 
average annual and maximum summer/autumn TP concentrations by calculating monthly means, seasonal means, and then annual means. For quality assurance purposes, the monitoring data for each lake were considered sufficient to perform these calculations only if they were available from at least two different months in each season, and at least three seasons within each year. Seasons were defined as spanning three calendar months, with winter, spring, summer and autumn starting in December, March, June and September, respectively; data for December were included in the winter season of the following year. For the purposes of this study, a lake was deemed to have failed WFD water quality targets for TP if the annual mean TP concentration was above the type or site specific good/moderate boundary value for TP provided by the Environment Agency.

\section{Lake pressures and responses}

Eutrophication pressures and lake responses, especially in relation to $\mathrm{P}$ enrichment, are driven, mainly, by water and nutrient supply, and moderated by lake sensitivity factors such as size, shape and water retention time. Lake responses to changes in TP inputs, hydrology and in-lake TP concentrations, were calculated as detailed below.

\section{Hydrology}

The annual input of water to the lake $\left(W_{\text {in }} \mathrm{m}^{3} / \mathrm{y}\right)$ was calculated by summing the HER (runoff) from the catchment $\left(W_{H E R} \mathrm{~m}^{3} / \mathrm{y}\right)$ and the annual input of rain falling directly onto the surface of the lake $\left(W_{\text {rain }} \mathrm{m}^{3} / \mathrm{y}\right)$ :

$$
W_{\text {in }}=W_{H E R}+W_{\text {rain }}
$$

The annual outflow from each lake $\left(W_{\text {out }} \mathrm{m}^{3} \mathrm{y}\right)$ was calculated as the annual input of water to the lake $\left(W_{i n}\right)$ minus the amount of water lost in evaporation over the surface of the lake ( $W_{\text {evap }}$ $\mathrm{m}^{3 / y}$ ):

$$
W_{\text {out }}=W_{\text {in }}-W_{\text {evap }}
$$

The water retention time of each lake ( $T_{w}$ lake volumes/y) was calculated as the volume of the lake $\left(V_{L} \mathrm{~m}^{3}\right)$ divided by the amount of water leaving the lake via its outflow $\left(W_{\text {out }} \mathrm{m}^{3 / y}\right)$ :

$$
\begin{gathered}
T_{w}=\frac{}{V_{L}} \\
W_{\text {out }}
\end{gathered}
$$

\section{Total phosphorus input to the lake}

The TP input (external loading) to each lake (TP in $\mathrm{t} / \mathrm{y}$ ) was estimated from lake specific TP delivery values derived from SEPARATE, as described above, plus the input of TP from rain falling directly onto the lake surface $\left(T P_{\text {rain }}\right) \cdot T P_{\text {rain }}(\mathrm{t} / \mathrm{y})$ was calculated as follows:

$$
T P_{\text {rain }}=\frac{}{\left(W_{\text {rain }} \times 0.45\right)}
$$

with $0.45 \mathrm{mg} / \mathrm{m}^{3}$ being the average concentration of TP in rainfall across the UK (Neal et al., 2004; Duethmann et al., 2009; Zhang et al., 2014). In addition, the percentage contribution of TP from agricultural sources $\left(\% T P_{a g} \mathrm{t} / \mathrm{y}\right)$ was calculated by dividing the TP input from this source $\left(T P_{a g}\right.$ $\mathrm{t} / \mathrm{y})$ by the total TP input to the lake $\left(T P_{\text {in }}\right)$ :

$$
\% T P_{a g}=\frac{}{T P_{a g}} \times 100
$$

\section{Lake response}

The response of each lake to external TP loading, in terms of its in-lake TP concentration $\left(\mathrm{mg} / \mathrm{m}^{3}\right)$, was estimated using a modelling approach similar to that used by OECD (1982). Only 85 lakes had sufficient TP monitoring and loading data to be included in these analyses. Initial results showed that none of the regional models published by OECD (1982) predicted the measured annual mean in-lake TP concentrations $\left(T P_{L}\right)$ of the lakes in England and Wales well. So, the 'combined' model was re-calibrated to improve the goodness-of-fit by adjusting the multiplication and power factors in the model to maximise the $\mathrm{r}^{2}$ value of a linear regression of the modelled and measured in-lake TP data. This produced the following predictive equation: 


$$
\begin{aligned}
& T P_{L}=0.13 \times X^{0.9} \\
& \text { where } X=\frac{}{T P_{i n} \times 10^{9}} /\left(1+\sqrt{T}_{w}\right) \\
& W_{\text {in }}
\end{aligned}
$$

The relationship between measured and modelled in-lake TP concentrations is shown in figure 1 ; the $\mathrm{r}^{2}$ of 0.72 indicates that the model accounts for about $72 \%$ of the variation between the modelled and measured data. Also, it should be noted that the level of uncertainty in the modelled values increases as the in-lake TP concentrations increase. Higher in-lake TP levels tend to correspond to shallow lakes $(<4 \mathrm{~m}$ depth) and the modelled values are more likely to underestimate the measured values in these systems. It is likely that this reflects the internal loading of $\mathrm{P}$ that is common in shallower lakes and is not taken into account in the TP loading data from SEPARATE.

The equation derived from these data was used to predict $i n^{-l a k e ~ T P ~ c o n c e n t r a t i o n s ~ f o r ~ a l l ~}$ lakes where TPin could be estimated reliably from the SEPARATE data, and where values for

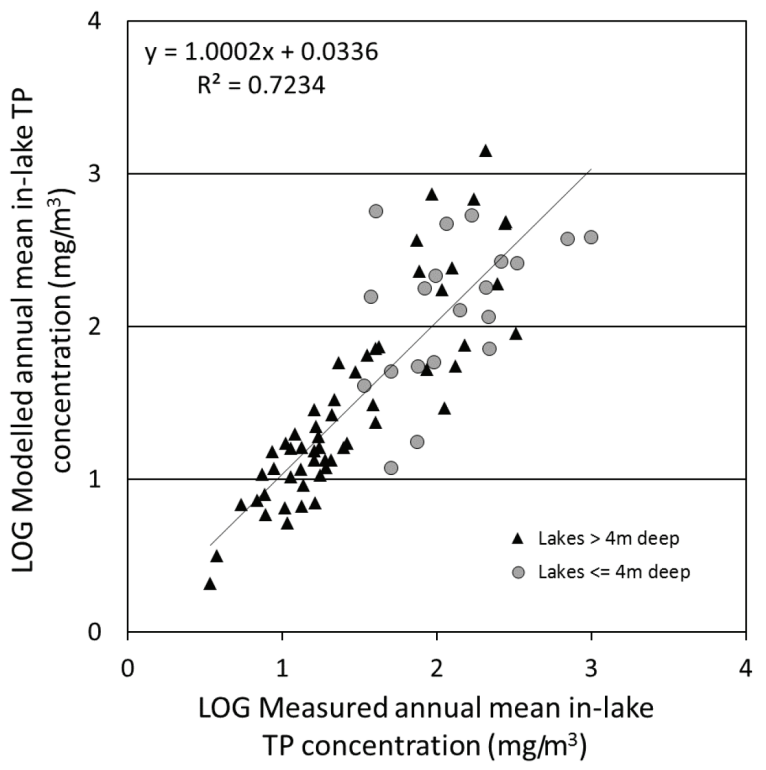

Figure 1. Relationship between measured and modelled in-lake total phosphorus (TP) concentrations for shallow $(<=4 \mathrm{~m})$ and deep ( $>4 \mathrm{~m}$ ) lakes. Relación entre las concentraciones del fósforo total (TP), medidas y modeladas, para lagos poco profundos $(<=4 m)$ y lagos profundos $(>4 m)$.
$W_{i n}$ and $T_{w}$ were also available $(\mathrm{n}=280)$.

\section{Critical total phosphorus load}

The WFD TP good/moderate boundary value for each lake was used, in combination with the lake response model, to determine the critical TP load below which the modelled in-lake TP concentration would be classified as 'good'. WFD water quality targets for TP concentration were available for only 97 of the 249 lakes that had sufficient data to calculate in-lake TP concentrations.

The estimated critical TP loads for these lakes were compared to the modelled TP loads to estimate the minimum reduction in TP inputs that

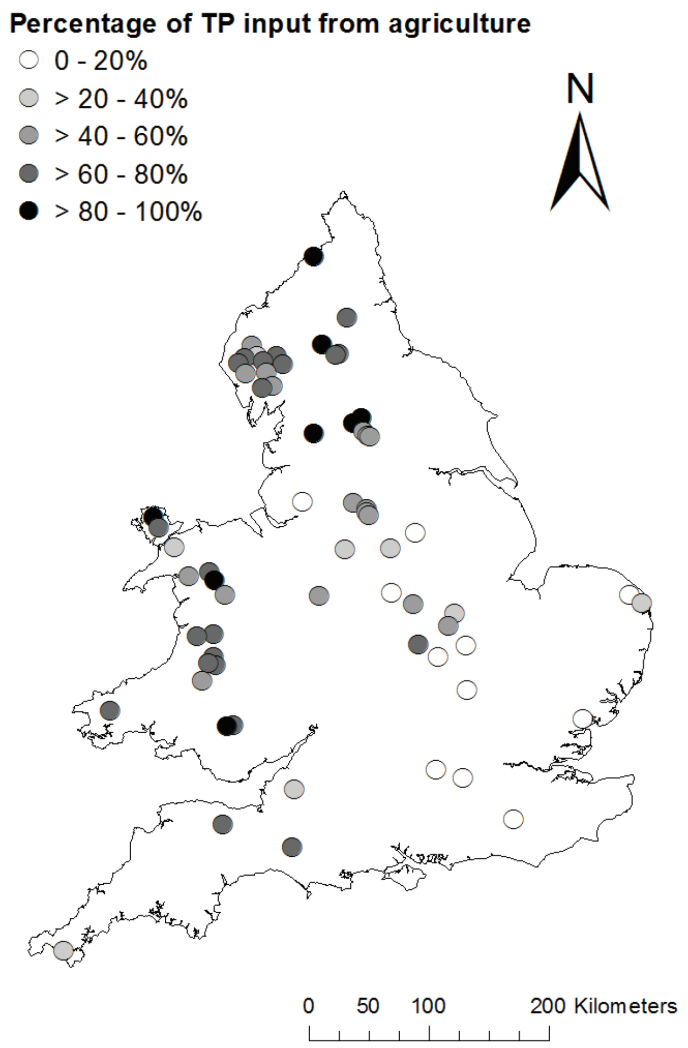

Figure 2. Percentage of the total phosphorus (TP) inputs to lakes in England and Wales that are attributable to agricultural sources, according to SEPARATE source apportionment data; lakes with catchments of $<25 \mathrm{~km}^{2}$ are excluded (see text for details). Porcentaje de las aportaciones del fósforo total (TP) a lagos en Inglaterra y Gales que se atribuyen a fuentes agrícolas, de acuerdo con los datos proporcionados por SEPARATE; se han excluido los lagos cuya cuenca es menor de $25 \mathrm{~km}^{2}$ (detalles en el texto). 
would be required to achieve good water quality. The technically feasible impacts of $0 \%, 5 \%, 10$ $\%, 15 \%, 20 \%, 25 \%, 50 \%$ and $75 \%$ reductions in TP inputs from agricultural sources on lake water quality were determined for each lake.

\section{RESULTS}

The percentage of the TP load to each lake that was originating from agricultural sources was mapped for all lakes in England and Wales where sufficient data were available (Fig. 2). The results showed that agriculture was not the main source of TP inputs to lakes in many areas. In these areas, other sources such as effluent from wastewater treatment works dominated these inputs. Lakes that were found to be failing WFD TP targets for at least good status were compared to those that were predicted to fail under current TP loading conditions using the modelling approach described above. Of the 85 lakes for which comparable data were available, failure to meet TP water quality targets for good status was correctly predicted in $89 \%$ of cases.

The water quality of the 99 lakes for which modelled data were available were classified as 'pass' or 'fail' in terms of meeting good status under different agricultural TP load reduction

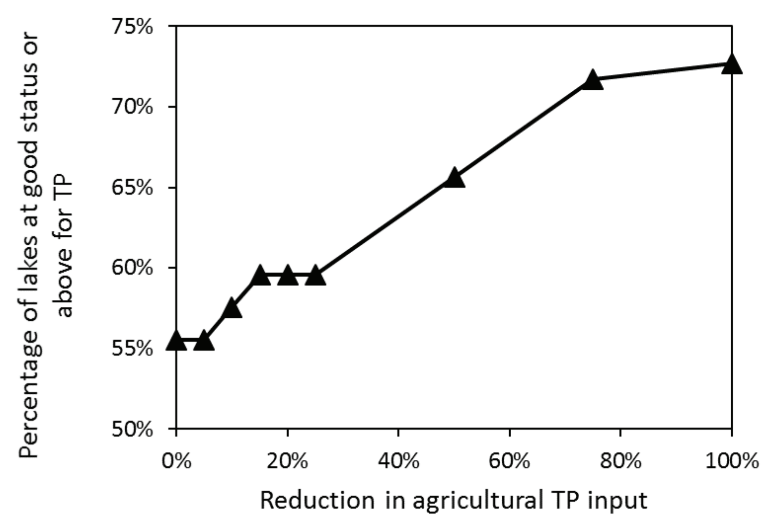

Figure 3. Number of lakes in England and Wales that would achieve WFD good status for total phosphorus (TP) concentrations under different levels of reduction in TP inputs from agricultural sources. Número de lagos de Inglaterra y Gales que podrian alcanzar el buen estado para la concentración de fósforo total (TP) según la DMA bajo diferentes niveles de reducción en los aportes de TP de origen agrícola. scenarios. The lake model predicted that, if the TP loads from agricultural sources were reduced, more lakes would pass WFD TP targets (Fig. 3). However, it also predicted that, even with a 100 $\%$ reduction in TP load from agricultural sources, $27 \%$ of failing lakes in England and Wales would still not meet the criteria for good status. This is due to other (non-agricultural) sources of TP within their catchments (Zhang et al., 2014).

To provide spatial detail on failing lakes across England and Wales, these data were mapped. The progressive improvement in lake water quality corresponding to $0 \%, 25 \%, 50 \%$ and $75 \%$ reductions in TP from agricultural sources is shown in figure 4 .

\section{Critical TP loads}

Critical TP loads were calculated for the good/moderate WFD boundaries of the 99 lakes for which sufficient data were available. Sixty-four lakes were found to have TP inputs that were above the critical TP load (with 63 being more than $10 \%$ above) and 35 had TP inputs below the critical TP load (with 33 being more than $10 \%$ below).

\section{Using the results to create a decision tree for lake management and restoration}

The results summarised above were used to develop the first phase (Phase 1) of a decision tree to help lake managers and regulatory authorities determine which of the lakes that are failing WFD water quality targets for TP would be likely to recover sufficiently to meet those targets if inputs from agricultural sources were reduced. The second phase of this development (Phase 2), aimed to identify lakes where recovery is likely to be delayed, or even prevented, by site specific factors that cause resistance to recovery. These include internal recycling of $\mathrm{P}$ within the lake, lake depth, fetch, hydraulic loading, the presence of benthivorous fish and the extent of the littoral zone (Janse et al., 2008).

Phase 1: Identifying lakes that are likely to achieve good status for total phosphorus if inputs from agricultural sources are reduced 
No reduction in agricultural TP load

- Pass

- Fail

$\square$ England \& Wales

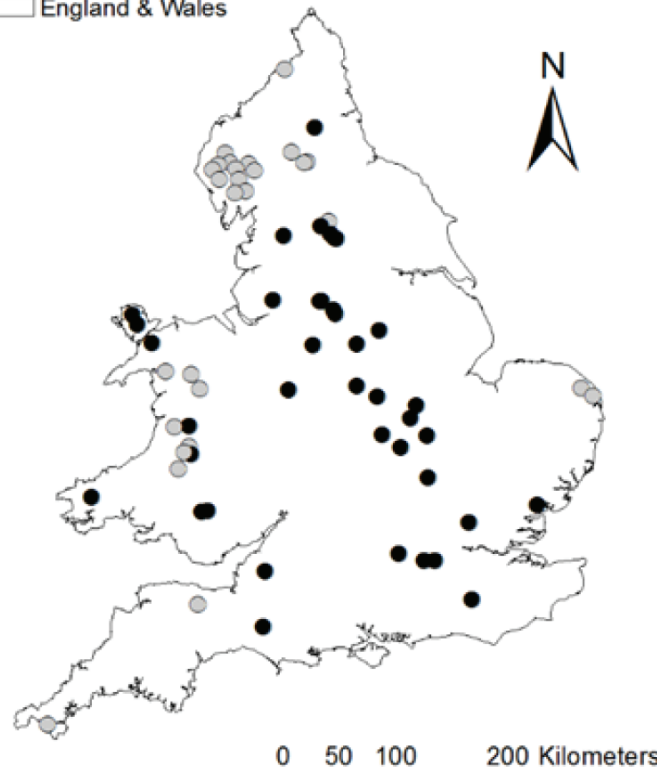

$25 \%$ reduction in agricultural TP load

- Pass

- Fail

$\square$ England \& Wales

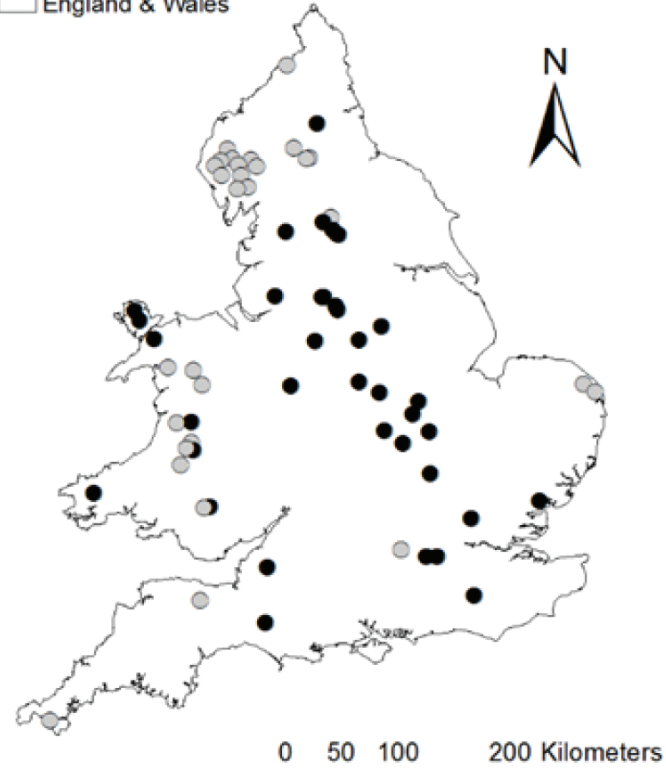

$\mathbf{5 0} \%$ reduction in agricultural TP load

$\mathbf{7 5} \%$ reduction in agricultural TP load

- Pass

- Pass

- Fail

- Fail
$\square$ England \& Wales

$\square$ England \& Wales
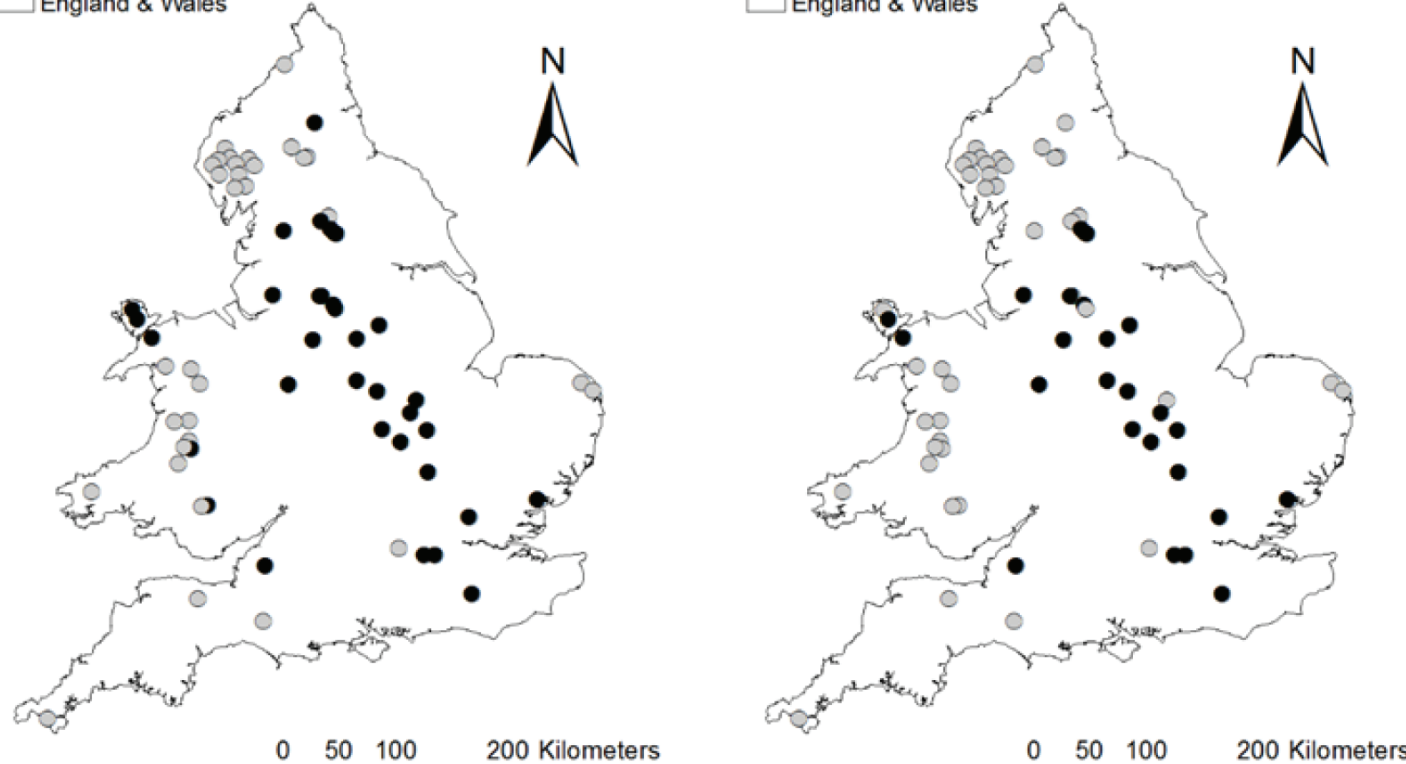

Figure 4. Lakes in England and Wales that are predicted to pass or fail WFD water quality targets based on the good/moderate boundary for total phosphorus (TP) under $0 \%, 25 \%, 50 \%$ and $75 \%$ reductions in agricultural loads. Lagos de Inglaterra y Gales que se predice que alcanzarán o no los objetivos de calidad de la DMA, según el límite bueno/moderado para fósforo total (TP) bajo reducciones en $0 \%, 25 \%, 50 \%$ y $75 \%$ de las cargas agrícolas. 


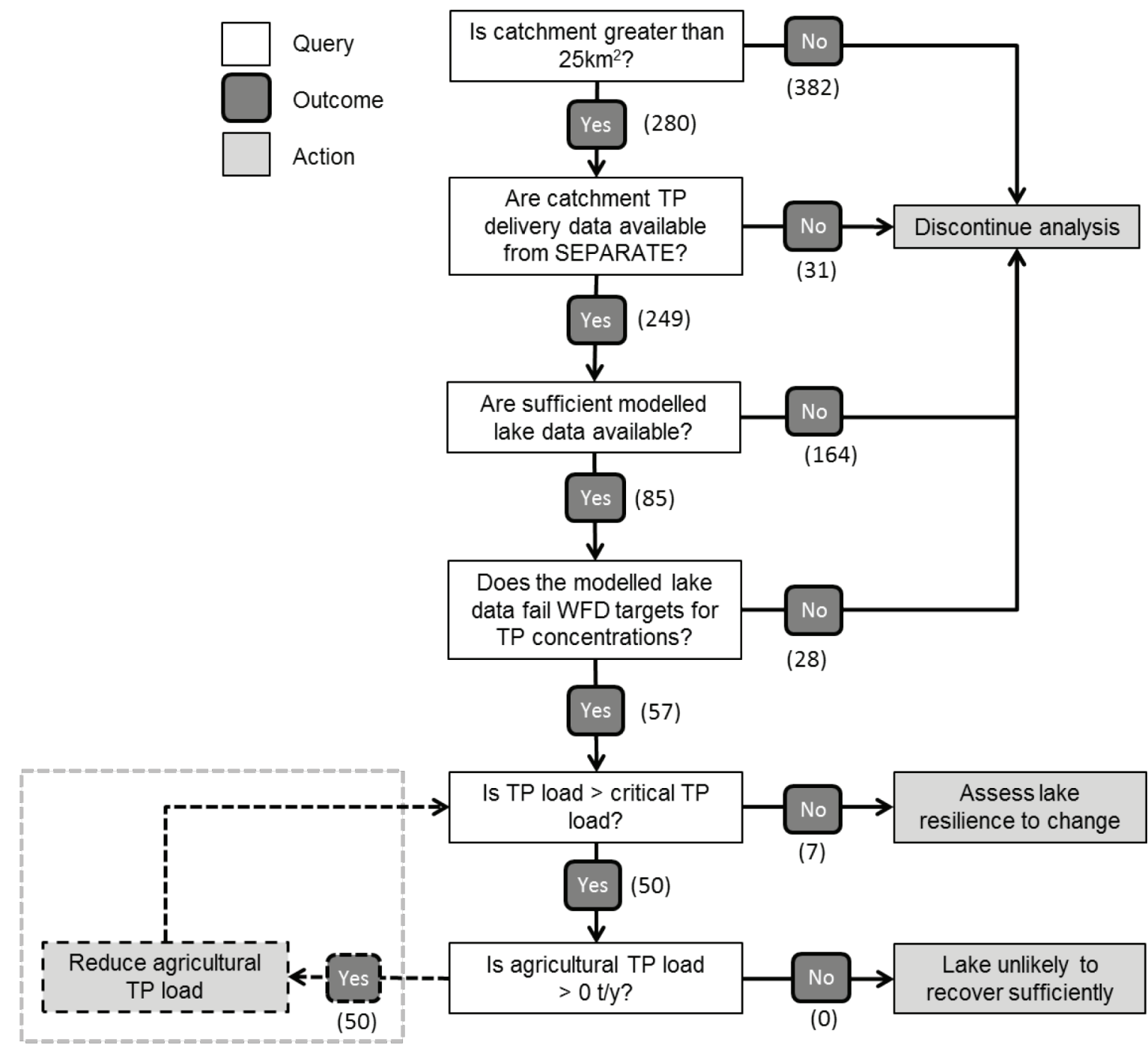

Figure 5. Phase 1 of the decision making process; identifying lakes that are likely to achieve WFD good status for TP concentrations if inputs from agricultural sources are reduced. The number of lakes being passed from step to step is shown in brackets. Fase 1 del proceso de toma de decisiones; identificación de los lagos que podrían alcanzar el buen estado según la DMA para las concentraciones de TP si se reducen las cargas de origen agrícola. El número de lagos que pasan al siguiente nivel están entre paréntesis.

A decision tree was constructed to help identify lakes that are likely to achieve good status in relation to TP concentrations following a reduction in TP inputs from agricultural sources (Fig. 5). The first step in this process excludes all lakes that have catchments smaller than $25 \mathrm{~km}^{2}$ in area because the SEPARATE nutrient load data are unreliable at this scale, especially for agricultural sources. This problem is caused by the underpinning process-based model for the agricultural sector, which uses aggregated statistical input data (Zhang et al., 2014). The second step examines whether TP loading information are available for each lake, with analysis being discontinued for lakes that do not have these data. The third step excludes all lakes for which there are insufficient monitoring data to provide robust information on annual average and summer/autumn maximum in-lake TP concentrations (see Methods section for details). In Step 4, the modelled lake 
data are compared to the WFD boundary values provided by the Environment Agency to determine whether or not they are failing WFD water quality targets; only those that are failing are passed through to Step 5. Step 5 assesses the likelihood of lakes recovering to at least good status if TP loads from agricultural sources are reduced. This step makes the assumption that any lake where the TP load is at, or below, the critical TP load is likely to recover, eventually. At this stage, any remaining lakes are passed through to Phase 2 of the decision tree (Fig. 6), where the inherent resistance of the lake to restoration efforts is assessed because this is likely to slow the recovery process (see below).

The increasing number of lakes that fall into the 'likely to recover' category as TP inputs from agricultural sources are progressively reduced are shown in table 1 . However, it should be noted that, in practice, even a $25 \%$ reduction in TP losses from agriculture would be difficult to achieve, unless uptake of on-farm mitigation measure is high (Collins et al., 2016; Zhang et al., 2017).

\section{Phase 2: Identifying lakes where resilience will delay recovery}

The 23 lakes that were assessed as being likely to recover if agricultural inputs are reduced (Table 1) were then examined for their level of resistance to restoration activities. Resistance, which can be caused by the interplay of a range of factors, reduces the rate of recovery even when external inputs of TP have been reduced. Some of these factors (e.g. internal release of $P$ from the sediments, lake depth $<4 \mathrm{~m}$, fetch $<3 \mathrm{~km}$ and

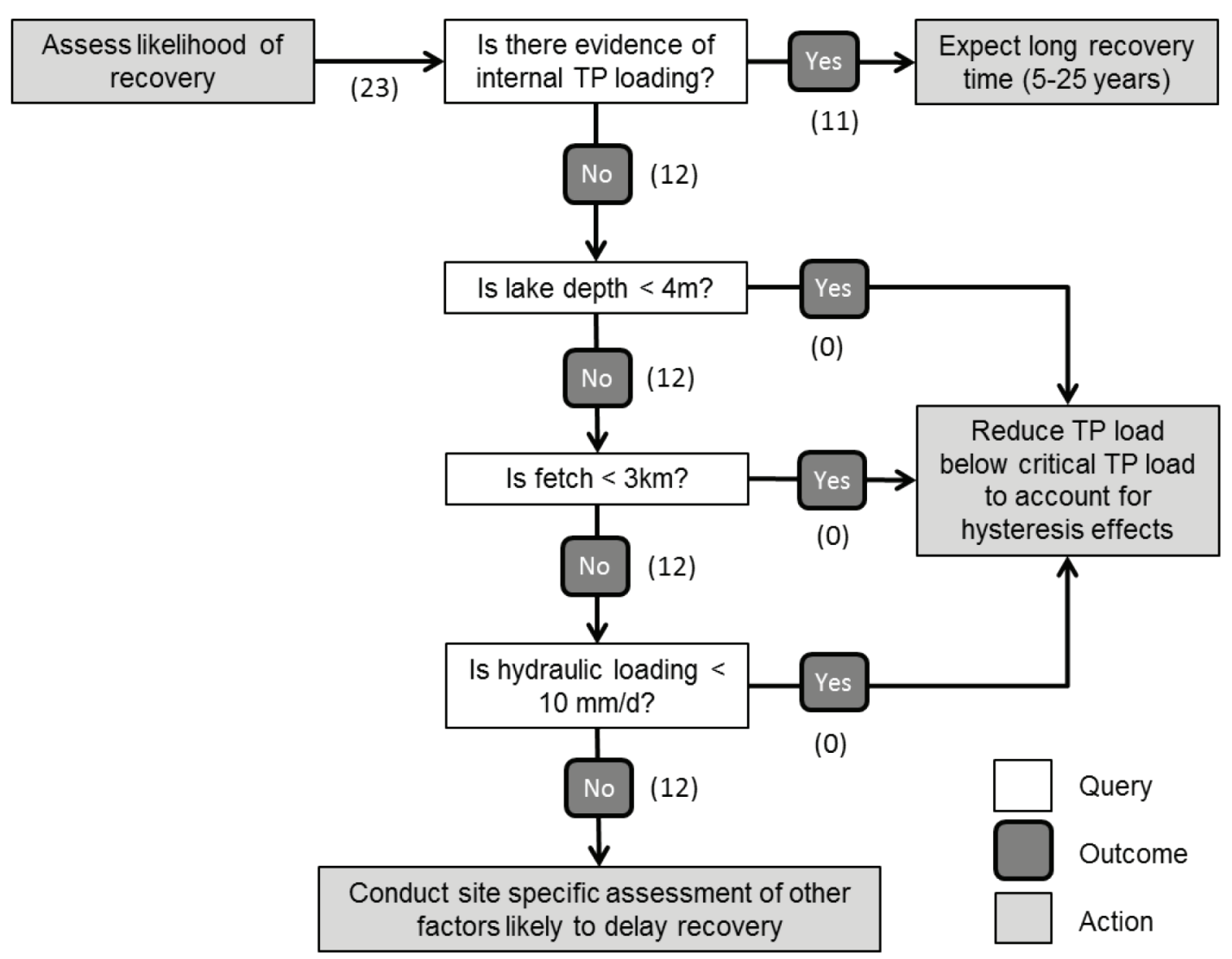

Figure 6. Phase 2 of the decision making process; identifying lakes where resilience to change is likely to delay recovery. The number of lakes being passed from step to step is shown in brackets. Fase 2 del proceso de toma de decisiones; identificación de los lagos donde la resiliencia al cambio es probable que retrase la recuperación. El número de lagos que pasan al siguiente nivel están entre paréntesis. 
hydraulic loading $<10 \mathrm{~mm} / \mathrm{d}$ - Janse et al., 2008) were attributed with numerical, or surrogate, values that can be used during the decision making process to screen out lakes that are likely to have a high resistance to restoration efforts (Fig. 6), and therefore long recovery times.

In Phase 2, Step 1 separates out the lakes where recovery is likely to be delayed by internal release of TP from the sediments. This TP is likely to have accumulated within the lake as a result of legacy pollution issues, such as effluent from wastewater discharges or agricultural runoff. The decision making process assumes that high maximum summer/autumn TP concentrations indicate high internal sources, because this is the time of year when large releases of P from lake sediments are most common. The criterion for this is set at summer/autumn in-lake maximum TP concentrations of more than $0.05 \mathrm{mg} / \mathrm{l}$.

Lakes that are deemed not to show evidence of internal P loading are subsequently assessed in relation to other factors that may delay recovery (Steps 2-4). These factors are lake depth, fetch and hydraulic loading. Lakes with a depth of less that $4 \mathrm{~m}$ tend to have more extensive macrophyte coverage than deeper lakes, which tends to delay recovery. Similarly, those with a maximum fetch of less than $3 \mathrm{~km}$ (Step 3), or a with very low flushing rate (Step 4), also tend to recover slowly. Very low flushing rate was approximated to a hydraulic loading of $<10 \mathrm{~mm} / \mathrm{d}$. In all of these cases, hysteresis effects are likely to occur when TP inputs are reduced. So, external TP loads may need to be reduced below the modelled critical TP load to compensate for this process during lake restoration.

Lakes that pass through Steps 1-4 then pass into the 'Conduct site specific assessments of other factors likely to delay recovery' action box. At this point, lakes are screened for other potentially confounding factors, such as the density of benthivorous fish or the extent of the littoral zone, which also affect the likelihood and speed of recovery. As these cannot be quantified at national scale, site specific assessments would be required to estimate the likely impact of these on lake recovery processes.

The decision process outlined above identified only 23 lakes as having potential to recover if external TP loads from agricultural sources were reduced (Table 1). Following assessment of the confounding factors shown in figure 6 , it was found that only 12 of these lakes were likely to recover quickly (i.e. in less than 5 years). Even then, this level of recovery could be achieved only if TP inputs from agricultural sources were reduced by an unrealistic $100 \%$.

The use of the proposed decision tree is illustrated using readily available lakes monitoring data from England and Wales, lake characteristics taken from the UK Lakes database (Hughes $e t$ al., 2004), and external TP loadings derived from

Table 1. Change in the number of lakes where total phosphorus (TP) load $>$ critical TP load under different levels of reduction in the TP load from agricultural sources. Cambio en el número de lagos donde la carga de fósforo total (TP) es mayor que el valor crítico de carga de TP, bajo diferentes niveles de reducción de la carga de TP de origen agrícola.

\begin{tabular}{ccc}
\hline $\begin{array}{c}\text { Reduction in TP input } \\
\text { from agriculture }\end{array}$ & $\begin{array}{c}\text { Number of lakes where } \\
\text { TP load }>\text { critical TP load }\end{array}$ & $\begin{array}{c}\text { Number of lakes where } \\
\text { TP load } \leq \text { critical TP load }\end{array}$ \\
\hline $0 \%$ & 50 & 7 \\
$25 \%$ & 50 & 7 \\
$50 \%$ & 44 & 13 \\
$75 \%$ & 38 & 19 \\
$100 \%$ & 34 & 23 \\
\hline
\end{tabular}


the SEPARATE (version 2.0) load apportionment model (Zhang et al., 2014). The results suggest that, of the 280 WFD lakes in England and Wales with catchments greater than $25 \mathrm{~km}^{2}$ in area, most had corresponding TP loading data available but only 85 had sufficient modelled data to complete the assessment process. Of these, 57 lakes were found to fail WFD water quality targets for TP concentrations at the good/moderate boundary. In almost all of these cases, the TP load to the lake was predicted to exceed the critical load even if agricultural losses were to be significantly, and unrealistically, reduced. These results suggest that reducing agricultural sources of TP within lake catchments would not be able to improve lake water quality sufficiently to meet WFD water quality targets unless combined with other nutrient reduction strategies. Of the 23 lakes that were identified as having the potential to recover to good water quality if agricultural TP inputs were reduced, 11 showed evidence of internal release of $\mathrm{P}$ from the sediments, which could delay recovery for many years.

\section{DISCUSSION}

At present, the selection of an appropriate restoration programme for any particular lake, or set of lakes, requires water quality managers to have a detailed understanding of external and internal sources of $\mathrm{P}$ to their lake and of the likely ecological responses to those loads (Moss et al., 1996). So, designing and implementing a lake restoration plan can be time consuming and expensive, with positive results only being achieved after long periods of recovery (Carvalho \& Kirika, 2003, Jeppesen et al., 2005, Moss et al., 2005, Phillips et al., 2005, Spears et al., 2007). Although difficult at the site specific scale, this situation is even more challenging where there is a need to assess lake restoration requirements and likely outcomes at a regional or national scale.

In this study, we developed a process to help water managers assess the extent to which failing lakes across a large area would be likely to meet WFD water quality targets for TP if inputs from agricultural sources, alone, were reduced. Our approach builds on a decision making process that was originally developed to identify failing lakes that would be suitable for another management approach, namely the control of internal P recycling using a geo-engineering approach (Spears $e t$ al., 2011). Our new approach is illustrated using WFD monitoring data from England and Wales.

The decision making process that we have proposed allows operational monitoring data from a large number of lakes to be summarised, screened, and categorised into suitable management categories on a national scale. The process uses decision criteria that are based on scientific evidence, thus making research results available to lake managers and regulatory authorities in a readily usable form and, thereby, reducing the level of uncertainty in the outcome. In particular, a Phase 2 decision tree has been added to that proposed by Spears et al. (2011). This enables candidate lakes to be assessed for their resistance to restoration, as this may affect the timing and cost-effectiveness of any management activity that is undertaken.

One of the limitations of earlier versions of the decision tree was its complete reliance upon sufficient lake monitoring data being available for all of the lakes being screened. In contrast, this new version takes a more modelling based approach. This allows a patchwork of monitoring data to be used to calibrate models that can be used to address gaps in data at national scale.

Although this study presents a large step forward in the development of a decision support framework for data managers, it also demonstrates that the data collected by routine monitoring surveys are often unsuitable for this purpose. While they show which lakes are degraded/degrading, they are of limited use in separating catchment inputs of $\mathrm{P}$ from those resulting from internal release from lake sediments. Further research is needed to address this issue and enable restoration measures to be applied cost effectively.

\section{CONCLUSIONS}

The proposed lake screening tool, which is based on lake characteristics and monitoring data that are routinely collected for regulatory and reporting purposes, can be applied at national scale to assess the suitability of lakes for a wide range of management techniques. It also provides a 
science based assessment for use by non-specialists, although it should be noted that this tool is not a substitute for the detailed understanding of individual lakes and lake processes that are required before embarking on costly restoration measures at any particular site. No national scale datasets include the site specific detail that may be critical to the success of restoration activities.

The small number of lakes passing through the screening process illustrates how confounding factors are often present when trying to assess why a lake has failed to meet water quality targets. Although data availability had the greatest impact on the effective use of earlier versions of this lake screening tool, this problem has been addressed, to some extent, in this version by incorporating a simple lake model into the decision making process.

The dataset used in this study demonstrates that there a very few lakes across England and Wales that could be restored to good water quality by reducing external inputs from agricultural sources alone. More generally, reducing the external TP load from agricultural sources would be effective only if introduced as part of a more comprehensive programme of restoration measures targeting other sources of TP, such as waste water treatment works, and taking into account site-specific factors that affect lake response. These include the extent to which historical nutrient inputs that have accumulated in lake sediments will be released into the water column during the recovery process.

\section{ACKNOWLEDGEMENTS}

This study was funded by the UK Department for Environment Food \& Rural Affairs, via project WQ0223 Developing a field toolkit for ecological targeting of agricultural diffuse pollution mitigation measures. The input of A.L. Collins was also supported by strategic funding from the UK Biotechnology and Biological Sciences Research Council (BBSRC) via grant BBS/E/C/000I0330.

\section{REFERENCES}

CARVALHO, L. \& A. KIRIKA. 2003. Changes in shallow lake functioning: response to climate change and nutrient reduction. Hydro- biologia, 506, 789-796. DOI: 10.1023/B: HYDR.0000008600.84544.0a

COLLINS, A. L., Y. S. ZHANG, M. WINTER, A. INMAN, J. I. JONES, P. J. JOHNES, W. CLEASBY, E. VRAIN, A. LOVETT \& L. NOBLE. 2016. Tackling agricultural diffuse pollution: What might uptake of farmer-preferred measures deliver for emissions to water and air? Science of the Total Environment, 547: 269-281. DOI: 10.1016/j.scitotenv. 2015.12.130

COMBER, S. D. W., R. SMITH, P. DALDORPH, M. J. GARDNER, C. CONSTANTINO \& B. ELLOR. 2018. Development of a chemical source apportionment decision support framework for lake catchment management. Science of the Total Environment, 622: 96-105. DOI: 10.1016/j.scitotenv.2017.11.313

DUETHMANN, D., S. ANTHONY, L. CARVALHO \& B. SPEARS. 2009. A model-based assessment of non-compliance of phosphorus standards for lakes in England and Wales. International Journal of River Basin Management, 7: 197-207. DOI: 10.1080/15715124.2009.9635383

EUROPEAN PARLIAMENT. 2000. Directive of the European Parliament and of the Council 2000/60/EC establishing a framework for community action in the field of Water Policy. PE-CONS 3639/1/00.

HOUGH, M. N. \& R. J. A. JONES. 1997. The United Kingdom Meteorological Office rainfall and evaporation calculation system: MORECS version 2.0-an overview. Hydrology and Earth System Science, 1: 227-239. DOI: 10.5194/hess-1-227-1997

HUGHES, M., D. D. HORNBY, H. BENNION, M. KERNAN, J. HILTON, G. PHILLIPS \& R. THOMAS. 2004. The Development of a GIS-based Inventory of Standing Waters in Great Britain together with a Risk-based Prioritisation Protocol. Water, Air and Soil Pollution: Focus, 4: 73-84. DOI: 10.1023/B:WAFO. 0000028346.27904.83

JANSE, J. H., L. N. DE SENERPONT DOMIS, M. SCHEFFER, L. LIJKLEMA, L. VAN LIERE, M. KLINGE \& W. M. MOOIJ. 2008. Critical phosphorus loading of different types of shallow lakes and the consequences for 
management estimated with the ecosystem model PCLake. Limnologica - Ecology and Management of Inland Waters, 38: 203-219. DOI: 10.1016/j.limno.2008.06.001

JEPPESEN, E., M. SØNDERGAARD, J. P. JENSEN, K. E. HAVENS, O. ANNEVILLE, L. CARVALHO, M. F. COVENEY, R. DENEKE, M. T. DOKULIL, B. O. B. FOY, D. GERDEAUX, S. E. HAMPTON, S. HILT, K. KANGUR, J. A. N. KÖHLER, E. H. H. R. LAMMENS, T. L. LAURIDSEN, M. MANCA, M. R. MIRACLE, B. MOSS, P. NÕGES, G. PERSSON, G. PHILLIPS, R. O. B. PORTIELJE, S. ROMO, C. L. SCHELSKE, D. STRAILE, I. TATRAI, E. V. A. WILLÉN \& M. WINDER. 2005. Lake responses to reduced nutrient loading - an analysis of contemporary long-term data from 35 case studies. Freshwater Biology, 50: 1747-1771. DOI: $10.1111 / \mathrm{j} .1365-2427.2005 .01415 . x$

MOSS, B., G. PHILLIPS \& J. MADGWICK. 1996. A guide to the restoration of nutrient-enriched shallow lakes. Broads Authority, Norwich.

MOSS, B., T. O. M. BARKER, D. STEPHEN, A. E. WILLIAMS, D. J. BALAYLA, M. BEKLIOGLU \& L. CARVALHO. 2005. Consequences of reduced nutrient loading on a lake system in a lowland catchment: deviations from the norm? Freshwater Biology, 50: 1687-1705. DOI: 10.1111/j.1365-2427.2005.01416.x

NEAL, C., R. SKEFFINGTON, M. NEAL, R. WYATT, H. WICKHAM, L. HILL \& N. HEWITT. 2004. Rainfall and runoff water quality of the Pang and Lambourn, tributaries of the River Thames, south-eastern England. Hydrology and Earth System Science, 8: 601-613. DOI: 10.5194/hess-8-614-2004

OECD. 1982. Eutrophication of waters. Monitoring, assessment and control. OECD, Paris.

PHILLIPS, G., A. KELLY, J.-A. PITT, R. SANDERSON \& E. TAYLOR. 2005. The recovery of a very shallow eutrophic lake, 20 years after the control of effluent derived phos- phorus. Freshwater Biology, 50: 1628-1638. DOI: $10.1111 / \mathrm{j} .1365-2427.2005 .01434 . \mathrm{x}$

SCOTTISH GOVERNMENT. 2015. The river basin management plan for Scotland river basin district: 2015-2017. 44pp. https://www. sepa.org.uk/media/163445/the-river-basinmanagement-plan-for-the-scotland-riverbasin-district-2015-2027.pdf (accessed 10/9/18) SERRANO, L., M. REINA, X. D. QUINTANA, S. ROMO, C. OLMO, J. M. SORIA, S. BLANCO, C. FERNÁNDEZ-ALÁEZ, M. FERNÁNDEZ-ALÁEZ, M. C. CARIA, S. BAGELLA, T. KALETTKA, M. PÄTZIG. 2017. A new tool for the assessment of severe anthropogenic eutrophication in small shallow water bodies. Ecological Indicators, 76: 324-334. DOI: 10.1016/j.ecolind.2017.01.034

SPEARS, B. M., L. CARVALHO, R. PERKINS, A. KIRIKA \& D. M. PATERSON. 2007. Sediment phosphorus cycling in a large shallow lake: spatio-temporal variation in phosphorus pools and release. Springer Netherlands, Dordrecht.

SPEARS, B., B. DUDLEY, S. MABERLY \& L. MAY. 2011. Screening lakes using environment agency data to identify sites that would benefit from controlling internal phosphorus load. Environment Agency.

ZHANG, Y., A. L. COLLINS, N. MURDOCH, D. LEE. \& P. S. NADEN. 2014. Cross sector contributions to river pollution in England and Wales: Updating waterbody scale information to support policy delivery for the Water Framework Directive. Environmental Science \& Policy, 42: 16-32. DOI: 10.1016/ j.envsci.2014.04.010

ZHANG, Y., A. L. COLLINS, J. I. JONES, P. J. JOHNES, A. INMAN \& J. E. FREER. 2017. The potential benefits of on-farm mitigation scenarios for reducing multiple pollutant loadings in prioritised agri-environment areas across England. Environmental Science \& Policy, 73: 100-114. DOI: 10.1016/j.envsci. 2017.04.004

Con el apoyo de:
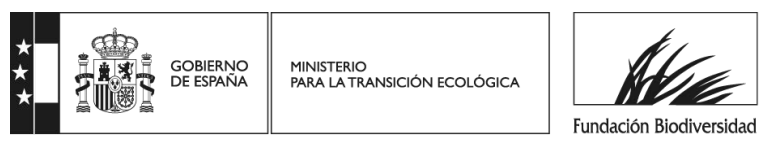